\title{
A Decision Framework for Investment in Supply Chain Driven Intermodal Systems
}

\author{
Hallock $S^{\text {a }}$
}

\begin{abstract}
A research study identifying the role of ports, a forward timeframe of 30 years in servicing national supply chains is being undertaken. A paradigm shift to 'water based' freight solutions by barges and other forms of Short Sea Shipping (SSS proposed in Hallock ${ }^{1,2}$ as well as investigating stakeholder commitment to reducing their carbon footprint will be researched as part of this. Funding and better investment criteria will also be explored. The paper draws on European policy and governance frame works incorporating SSS as a component of the logistics response to sustainability. The green supply chain is now an important determinant of competitive advantage and is commercially acceptable.
\end{abstract}

\section{Key words: Green Supply chain; Short-sea shipping; Infrastructure investment decisions; Ports; Policy frameworks.}

\section{Introduction}

Port and intermodal infrastructure decisions though impacting National Supply Chains, do not have an integrated framework within which they can be made. Such investments in Victoria and NSW will have a significant impact on urban form and create system interdependencies of surface transport but are logically evaluated locally with little consideration of national imperatives. Predictably States have assumed investment in surface transport to be, "more rail and road", to service cargo movement generated by a port.

A paradigm shift to "water based" solutions by barges and other forms of Short Sea Shipping (SSS) was proposed in Hallock ${ }^{\mathrm{i} 1,2}$. Such thinking would also be compatible with initiatives to promote sustainable transport and reduce the carbon footprint of freight. Greening the supply chain has been identified as an important component of the logistics response to sustainability. SSS is part of a policy framework in Europe and US and commercially acceptable. The green supply chain is now an important determinant of competitive advantage.

Major infrastructure decisions are best made using a 30 year strategic forward view, which will be used to identify and establish the role of major ports in servicing a National Supply Chain network. Exploration of; stakeholder's commitment to reducing their carbon footprint and adopting sustainable transport practices such as SSS; development of innovative funding mechanisms alternate project evaluation methodology, and exploring whether commercial returns on investment are compatible with such outcomes will be explored.

\footnotetext{
${ }^{a}$ Director- drh logistics International (pvt) ltd, Victoria 3150 and Colombo Sri Lanka http://dx.doi.org/10.14453/isngi2013.proc.19
} 


\section{Methodology}

A literature review has established several key concepts:

- Short Sea shipping is an environmentally sustainable mode of transport has a good fit with the greening of the supply chain.

- There is need for a paradigm shift in thinking in Australia in how sustainable transport occurs.

- Integrated thinking on investment in national logistics framework needs to occur.

A data collection phase not discussed in this paper will be based on interviews of key industry players including port operators, shipping lines, peak shipper bodies and will benchmark Australian adoption against International experience. The methodology will examine the use of Analytical Hierarchical Processing (AHP) within Multi-Criteria Decision Analysis (MCDA) frameworks and if possible Real options to arrive at a strategic decision based system usable by both state and Equity investors. The relevance to Federal research priorities as evidenced by the National Land Freight Strategy ${ }^{3}$ will be examined. Prima facie this strategy provides less of a platform for the research themes of the Australian Transport Council which was replaced.

\section{Literature Survey}

The survey of literature in the fields of SSS, supply chains, greening the supply chain, the role of ports and intermodal infrastructure, sustainable transport and investment in enabling infrastructure shows that there is a case to further explore these areas in the Australian context. No work has been done at an academic or industry level to explore opportunities or address all of the questions raised in a manner that attempts to integrate these streams of thought. A survey of literature to date suggests some of the themes are well supported as evidence presented below; on the other hand some themes require a more detailed survey of the literature-e.g. hubs in relation to Port -Supply chain interfaces and Port-Airport interfaces.

\section{Short Sea Shipping}

The benefits of using Short Sea Shipping (SSS) as an alternate or complement to, road and rail modes, for short haul freight of future cargo flows within Melbourne's east-west-east corridor, was canvassed in Hallock and Wilson (op.cit.). A subsequent paper (Hallock 2010) developed two aspects of value capture and competitive advantage within the supply chain (SC) strengthening the case for integrating SSS into the $\mathrm{SC}^{2}$.

The implication of Hallock et al is to provide a framework of exploring this theme. A detailed discussion on the variants of a definition for SSS is provided in Hallock et $\mathrm{al}^{1}$ and Medda and Trujillo ${ }^{4}$. In this paper we adopt Stopford's definition of short sea shipping (SSS) as "maritime transport within a region serving port to port feeder traffic in competition with land transport" cited by Musso and Marchese 5 in their discussion on a definition for SSS. Medda and Trujillo (op.cit) contribute something new to the discussion on definitions for SSS when they identify the intermodal importance of SSS, as both a complement to road or rail as 
well as being a competitor when the potential exists to provide a point to point alternative to land transport ${ }^{5,4}$.

\section{Alternatives to building infrastructure}

Federal and State research priorities around co-operative research, integrated research and action on environmental impacts as well as interdependencies with communities and stakeholders when reviewing long term land use for port cities will be examined.

\section{Value Capture in the supply chain}

Supply Chain Management (SCM) definitions use the concepts of "upstream and downstream" management of relationships, the delivery of value and the integration of suppliers (upstream) with customers (downstream), Christopher ${ }^{6}$, Mentzer et.al ${ }^{7}$. One definition of SCM is "a set of three or more entities (organizations or individuals) directly involved in the upstream and downstream flows of products, services, finances, and/or information from a source to a customer" Mentzer et.al ${ }^{8}$. A preferred definition, used in this paper, which incorporates the concepts of customer value and least cost, is SCM is the "management of upstream and downstream relationships with suppliers and customers to deliver superior customer value at less cost to the supply chain as a whole" 6 .

However recent thinking proposes that the supply chain is only part of the overall value chain and in fact requires the introduction of a demand chain to be a meaningful concept ${ }^{9}$. They go on to propose a model in which the cost efficiency and leanness of the SCM approach is supplemented by understanding customer and stakeholder expectations via demand chain processes. In their model of the value chain, supply chain decisions require the identification of a value proposition. This needs prior analysis of market attractivity, opportunity and organisational structure and resourcing. It is only then that the SCM decisions of value production and co-ordination can make sense. The advantage of the approach of Walters et al (op cit.) is that it emphasises value capture and value creation ${ }^{9}$. The application of the concept of value capture by integrating SSS into the SC can be explored further.

Value capture in global and domestic supply chains has hitherto focussed on efficiency e.g. techniques to compress lead times, reduce costs and improve customer service and recently lean concepts Levy ${ }^{10}$, Womack and Jones ${ }^{11}$. Value capture and value creation in a supply chain which relies on collaboration can be better understood from the point of view of Martinez $^{12}$ who proposes two aspects of value viz. internal focus on the creation of shareholder-wealth and the second external focus being from the customer's view and being satisfaction driven.

Value migration was identified by Slywotzky ${ }^{13}$ to be a phenomenon where value in an industry shifts over time and new business landscapes emerge; consequently outmoded business models give way to 'new ones better able to satisfy customers, ${ }^{13}$. Robinson ${ }^{14}$ takes the view that "pervasive value migration has created new value pools in port -oriented handling systems"14. For an excellent recent discussion of the concept relating to the pharmaceutical industry see Walters and Rainbird ${ }^{15}$. Value capture in these circumstances enables strategic positioning to ensure long term strategic advantage. 


\section{Ports and intermodal infrastructure}

A key change to the role of ports today is that ports are now takers not makers ${ }^{16}$. This hypothesis is supported in the literature ${ }^{17}$ but will be tested in data collection.

\section{Value capture in the supply chain through SSS}

In Hallock, value capture in the SC relating to port/terminal situations was explored ${ }^{2}$. The potential for value capture in the SC through incorporating SSS into the SC via the terminalisation model was specifically discussed in the paper.

The potential to capture value by integrating SSS into the SC thereby leading to competitive advantage for users interested in sustainable supply chains was the second theme explored. Examples were provided of recent corporate interest in greening the SC and the author argues that this is not only important from the enterprise's viewpoint but also a path along which logistics should evolve to maintain its relevance in the future.

The evidence that short sea shipping has a role in value capture in strategic supply chain decisions because of environment and sustainability drivers and concerns is presented in detail. What needs to be noted here is that large retailers such as Wal-Mart have already required a demonstration of environmental stewardship on the part of their suppliers (including a base-lining of Green-house Gas (GHG) emission per unit product). The implications for the SC in choosing low emission transport is immediately obvious. SSS offers a competitive advantage within the SC because it:

- Enables sustainability objectives to be met by users ${ }^{19}$.

- Minimises economic and environmental disbenefits ${ }^{27}$

- Allows unlocking of value by using a different operational paradigm ${ }^{17}$.

Examining each of these, there is evidence that concern with future impacts of present actions in environmental and sustainability areas is now informing the strategic SC and logistics choices made by commercial operators and policy choices of governments. The forwarder CONTARGO in the European North Continental Port range offers barges on both short routes of $50 \mathrm{~km}$ and longer routes with a matched value proposition to cargo needs. Three scenarios are offered: barge combination, truck only, rail combination, with $\mathrm{CO} 2$ emissions offsets provided for each scenario. ${ }^{18,19}$ An example of government policy is the; European Commission's Motorways of the Sea concept which stems from the Trans European Transport Networks and Marco Polo program. Marco Polo is the European Union's funding programme for projects which shift freight transport from the road to sea, rail and inland waterways. This means fewer trucks on the road and thus less congestion, less pollution, and more reliable and efficient transport of goods. For instance, "a motorway of the sea route could be developed along the Atlantic coast to provide a sea-lane running parallel to motorways" 20 .

Golicic, Boerstler and Elram ${ }^{21}$ observe that there are benefits to companies that integrate sustainability into their SC. They also note that freight transportation has moved from being of negligible consideration in company strategy to something monitored as a key part of SC sustainability practices, by both investors and customers. Golicic et.al surveyed 44 Fortune 
500 companies and identified 22 that were trying to significantly address greenhouse gas emissions from freight transport in the supply chain . The 22 used a mixture of technological and operational tactics to achieve their goals. Eleven companies including Dell, HP, Estee Lauder making strategic choices on mode shift; thirteen companies including Walmart and FedEx used tactics which required a change to their fleet practices, e.g. through using alternate vehicle types and fuels, wider truck tyres etc.

\section{Reducing environmental impacts}

The certainty that mode shift to SSS will result in economic and an environmental benefit has been extensively discussed in Hallock ${ }^{1}$ and elsewhere. The pollution mitigation potential of SSS is recognised by numerous authorities - Perakis ${ }^{22}$, Marlow $^{23}$ and the ECT via its Marco Polo Program (ECT 2005) ${ }^{22,23}$. In $\mathrm{EEC}^{27}$ data is provided showing the relative greenhouse gas (GHG) emissions by pollutant by mode ${ }^{24}$. $\mathrm{BTRE}^{25}$ notes the social costs of congestion $\$ 6.1$ bn for Melbourne by 2020 refers to estimated aggregate costs of delay, trip variability, vehicle operating expenses and motor vehicle emissions-associated with traffic congestion-being above the economic optimum level for the relevant network ${ }^{24}$. These costs are not "internalised" or paid for.

SSS is comparatively less polluting than road or rail. Australia has a national target of cutting greenhouse gas (GHG) emissions to 108 per cent of the levels they were in $1990^{26}$.

Table 1. Evidence from the EEC, Green House Gas emissions from transport by Tonnes Mn's.

\begin{tabular}{|l|l|l|l|l|l|l|l|l|l|l|l|}
\hline & $\begin{array}{l}\text { Air Total } \\
\text { Dom+Intnl }\end{array}$ & $\begin{array}{l}\text { Air } \\
\text { Dom }\end{array}$ & $\begin{array}{l}\text { Air } \\
\text { Intnl }\end{array}$ & Road & Rail & $\begin{array}{l}\text { Shipping } \\
\text { Total } \\
\text { Coastal } \\
\text { +Intnll }\end{array}$ & $\begin{array}{l}\text { Shipping } \\
\text {-coastal }\end{array}$ & $\begin{array}{l}\text { Shipping } \\
\text {-Intnl }\end{array}$ & Other & $\begin{array}{l}\text { Total } \\
\text { Trpt }\end{array}$ & $\begin{array}{l}\text { Total } \\
\text { Emissions }\end{array}$ \\
\hline $\begin{array}{l}\text { EU } \\
27 \\
\text { states }\end{array}$ & 155.4 & 25.6 & 129.8 & 902 & 7.8 & 194.6 & 23.4 & 171.3 & 10.1 & 1269.9 & 4558.7 \\
\hline
\end{tabular}

\section{Source EEC ${ }^{27}$}

The BTRE have published the following for Australia:

Table 2. Gigagrams of $\mathrm{CO} 2$ equivalent.

\begin{tabular}{|l|l|l|l|l|l|l|l|l|}
\hline & Cars & $\begin{array}{l}\text { Road } \\
\text { freight }\end{array}$ & Air & Rail & $\begin{array}{l}\text { Coastal } \\
\text { shipping }\end{array}$ & other & Total & \\
\hline 2000 & 40696 & 20762 & 4996 & 3518 & 1505 & 1980 & 73,456 & \\
\hline 2020 & 50110 & 31874 & 11922 & 4848 & 1359 & 2292 & 102,406 & \\
\hline
\end{tabular}

Table 3. Composition of non $\mathrm{CO} 2$ non electric modes 2020 in Gigagrams.

\begin{tabular}{|l|l|l|l|l|l|}
\hline & $\mathrm{NO}_{\mathrm{x}}$ & $\mathrm{CH}_{4}$ & NMVOC & $\mathrm{CO}$ & $\mathrm{N}_{2} \mathrm{O}$ \\
\hline Rail & 2623 & 64.4 & 0.23 & 21.8 & 0.08 \\
\hline $\begin{array}{l}\text { Coastal } \\
\text { shipping }\end{array}$ & 28.6 & 0.07 & 1.16 & 2.94 & 0.04 \\
\hline
\end{tabular}

Source Tables 2 and 3, BTRE op.cit -107 p $231 \& 213^{25}$.

\section{Innovation}


Unlocking value in a supply chain, of which SSS is an element also requires a change in the operational paradigm, in this case via the terminalisation model proposed by Rodrigue and Notteboom being extended to cover supply chains. Rodrigue and Notteboom have analysed the growing importance of two phenomena, gateway constraints and dwell times within the supply chain ${ }^{17}$.

The phenomena have been known to shipping practitioners but have only recently been considered by academics. The terminalisation model advocates the use of dwell times and a strategically widened role for terminal operators as a way value can be captured primarily by providing benefits in time and cost. The authors introduce the concept of modal separation of space and time, i.e. an opportunity for trading off time utility vs. space utility, as a means of unlocking value. The focus on buffer derived terminalisation is innovative. This is where there is an expectation that the warehouse becomes the buffer rather than more traditionally the distribution centre (DC). In essence it is an inventory in transit strategy which uses "inventory at terminal" to reduce warehousing cost and thereby total distribution cost.

It can succeed where DC/warehousing are costly and where shipping lines are chasing cargo. "Inventory in transit" was encountered by the author, when managing break bulk shipping (which did not always possess the clock work efficiency of container schedules) in trades having global supply chains. US and European consignees of some primary commodities and semi-processed agricultural produce preferred the slower transit time because it enabled them to use the vessel as a floating warehouse which phenomenon was recorded in Hallock $^{28}$. Since SSS is an activity potentially replacing landside transfers the terminalisation of the supply chain can be extended to incorporate SSS. By doing so it facilitates value capture cost efficiency leading to creation of shareholder wealth on the one hand and customer satisfaction to those who want a green supply chain.

The research will also examine the concept of a Global Logistics Region developed by $\mathrm{O}^{\prime} \mathrm{Connor}^{29}$. The application of this concept and identifying the pre requisites of large extended regions and the breadth of freight activity is innovative. It has not been applied to Australia.

\section{Decision criteria}

Decisions entailing uncertainty in strategic choices are not well handled by current evaluation techniques using variations of Benefit Cost Analysis. Although the use of structured "Gateway" processes by the State and Federal treasuries has helped, uncertainty has not been dealt with satisfactorily. The use of real options as done by Telstra (2003-2013) in the case of evaluating technology with variable outcomes combined with multiple criteria analysis tools like Analytical Hierarchy Process and are other multi-dimensional evaluation techniques that can also be utilized ${ }^{30}$. For projects over $\$ 750 \mathrm{M}$ a critical examination of Wider Economic Benefits (WEBS) is analysed with a view to establishing whether or not this technique offers more than the use of CGE modelling. These alternatives are considered as providing an integrating decision framework for the choices in the areas under discussion.

\section{Recommendation}

The themes introduced in this paper are particularly relevant for the renewed discussion on funding of national infrastructure. They will be initially explored as a part of a doctoral dissertation and a decision model proposed for use in Australia. 
International Symposium for Next Generation Infrastructure October 1-4, 2013, Wollongong, Australia 


\section{References}

${ }^{1}$ Hallock, S. and Wilson, D., 2009 Urban freight transport -the Short Sea Shipping alternative for Melbourne, Australian Transport Research Forum -ATRF, 2009.

${ }^{2}$ Hallock, S., SSS as an element of a Supply Chain for Melbourne's future East West Cargo flows, Australian Transport Research Forum -ATRF, 2010

${ }^{3}$ National Land Freight Strategy, Commonwealth of Australia, 2013.

${ }^{4}$ Medda, F., and Trujillo, L., "Short-sea shipping: an analysis of its determinants", Maritime Policy and Management, Vol. 37, No. 3, 2010, pp. 286-287. http://dx.doi.org/10.1080/03088831003700678

${ }^{5}$ Musso, E., and Marchese, U., "Economics of short sea shipping, Grammenos, C.T. (Editor), Handbook of Maritime Economics and Business, Lloyds of London Press: London, 2002.

${ }^{6}$ Christopher, M., Logistics and Supply Chain Management, Prentice Hall, 1998, p. 15-16.

${ }^{7}$ Mentzer, J. J., De Witt, W., Keebler, J. S., Min, S., Nix, N. W., Smith, C. D., and Zacharia, Z. G., "Defining Supply chain management", Journal of Business Logistics, Vol. 22, No. 2, 2001, pp. 1-25. http://dx.doi.org/10.1002/j.2158-1592.2001.tb00001.x

${ }^{8}$ Mentzer, J., Stank, T., and Esper, T., "Supply chain management and its relationship to Logistics, Marketing, Production and Operations Management", Journal of Business Logistics, Vol. 29, No. 1, 2008, pp. 31-46. http://dx.doi.org/10.1002/j.21581592.2008.tb00067.x

${ }^{9}$ Walters, D., and Rainbird, M., Strategic Operations Management a Value Chain approach, 2007, pp. 2, 18-20,157-158.

${ }^{10}$ Levy, D., "Lean production in an International Supply Chain", Sloan Management Review, Winter, 1997.

${ }^{11}$ Womack, J., and Jones, D., Lean Solutions: How Companies and Customers Can Create Value and Wealth Together, 2005.

${ }^{12}$ Umit, S. B., Martinez, V., Albores, P.1, Parung, J., "Creating and managing value in collaborative networks", International Journal of Physical Distribution \& Logistics Management, Vol. 34, No. 3-4, 2004, pp. 251-268.

${ }^{13}$ Slywotzky, A. J., Value Migration: How to Think Several Moves Ahead of the Competition, Harvard Business Press, 1996.

${ }^{14}$ Robinson, R., "Port oriented landside logistics in Australian ports: A strategic framework", Maritime Economics \& Logistics, Vol. 8, 2006, pp. 40-59. http://dx.doi.org/10.1057/palgrave.mel.9100149

${ }^{15}$ Walters, D., and Rainbird, M., Strategic Operations Management a Value Chain Approach, Palgrave Macmillan, 2007.

${ }^{16}$ Robinson, R., "Ports as elements in value-driven chain systems: the new paradigm". Maritime Policy \& Management, Vol. 29, no. 3, 2002, pp. 241-255. http://dx.doi.org/10.1080/03088830210132623

${ }^{17}$ Rodrigue, J.-P. and Notteboom, T., "The terminalization of supply chains: reassessing the role of terminals in port/hinterland logistical relationships", Maritime Policy \& Management, vol. 36, No. 2, 2009, pp. 165-183. http://dx.doi.org/10.1080/03088830902861086

${ }^{18} \mathrm{CI}$, "Contargo to expand Prouvy Barge Terminal", Containerisation International, Vol. 41, No. 10, 1 October, 2008, p 23.

${ }^{19} \mathrm{CI}$, "Amsterdam gets twice weekly barge service... as Rotterdam signs deal for new inland terminal”, Containerisation International, Vol. 41, no. 8, 1 August, 2008, p 29.

${ }^{20}$ EC, Transport Research APAS, Short Sea Shipping, Directorate Generale VII, European Commission: Luxembourg, 1996. 
${ }^{21}$ Golicic, S. L., Boerstler, C. N., and Elram, L. M., "'Greening' Transportation in the Supply Chain", Sloan Management Review, Winter, 2010.

${ }^{22}$ Perakis, A. N., and Denisis, A., "A survey of short sea shipping and its prospects in the USA", Maritime Policy and Management, vol. 35, No. 6, 2008, pp. 591-614. http://dx.doi.org/10.1080/03088830802469501

${ }^{23}$ Marlow, P. B., Petit, S. J., and Scorza, A.D., Short Sea shipping in Europe: Analysis of the UK and Italian markets, UWIST Department of Maritime Studies: Cardiff, 1997.

${ }^{24}$ EC, Marco Polo Program. Regulation (EC) No 1692/2006 of the European Parliament and of the Council of 24 October 2006 establishing the second Marco Polo programme for the granting of community financial assistance to improve the environmental performance of the freight transport system (Marco Polo II), European Commission: Luxembourg, 2006.

${ }^{25}$ BTRE, Estimating urban traffic and congestion cost trends for Australian cities. Working Paper 71, Bureau of Transport and Regional Economics: Canberra, 2007, URL: http://www.bitre.gov.au/publications/49/Files/wp71.pdf

${ }^{26}$ National Transport Commission, Annual Report 2009, URL: http://www.ntc.gov.au.

${ }^{27} \mathrm{EEC}$, ECT: Motorways of the sea, Directorate-General for Energy and Transport B1049(2005), EC Brussels, 2006, URL: http://europa.eu.int/comm/dgs/energy_transport/index_en.html

${ }^{28}$ Hallock, D. S., The regulation or promotion of shipping for development, MSc thesis, University of Wales: Cardiff, 1983.

${ }^{29}$ O'Connor, K., Global Logistics Regions a New Outcome in World Sea and Air Logistics, Monograph, University of Melbourne, 2011.

${ }^{30}$ Telstra corporation, Guideline to investment evaluation, (restricted circulation), various editions 2003 to 2013. 